\title{
LA RESPONSABILIDAD DEL GOBIERNO EN LOS ORÍGENES DEL CONSTITUCIONALISMO ESPAÑOL: EL ESTATUTO DE BAYONA
}

IGNACIO FERNÁNDEZ SARASOLA

Universidad de Oviedo 


\section{SUMARIO}

I. INTRODUCCIÓN.-II. SUJeto PASIVO Y REgLA GeNERAL DE RESPONSABILLDAD.-1. Regla general y responsabilidad jurídica. La figura del refrendo.-2. Regla general y responsabilidad individual.-III. Sujetos activos de La ResPonsabiLIDAD: LAS CoRTeS.-1. Problemática de la legitimación de las Cortes como órgano de control.2. Los medios de control del ejecutivo.-3. Naturaleza de la responsabilidad: la responsabilidad jurídica.-4. Naturaleza de la responsabilidad: hacia una responsabilidad política.-5. Instrumentos de exigencia de responsabilidad.-6. La cuestión de la publicidad de las sesiones.-7. El órgano sancionador: la Comisión.-IV. SuJeTos ACTIVOS DE LA RESPONSABILIDAD: EL SENADO.1. El Senado como órgano controlador y sujeto activo de responsabilidad.-2. El órgano sancionador: la Junta.-V. LA ALTA CORTE NACIONAL: PROBLEMÁTICA DE SU ARTICULACIÓN CONSTITUCIONAL.-VI. Conclusiones. 
Revista de Derecho Político, núm. 41, 1996, pp. 177-214

\section{LA RESPONSABILIDAD DEL GOBIERNO EN LOS ORÍGENES DEL CONSTITUCIONALISMO ESPAÑOL: EL ESTATUTO DE BAYONA (*)}

POR

IGNACIO FERNÁNDEZ SARASOLA

Universidad de Oviedo

\section{INTRODUCCIÓN}

El Estatuto de Bayona representa el primer ensayo constitucional de la historia española, a pesar de que la generalidad de la doctrina ha mantenido una opinión divergente', ya sea por su origen afrancesado, ya por su carácter de Carta Otorgada. Esta es la naturaleza que consideramos debe atribuirse al Estatuto. Por una parte, por la participación meramente consultiva que tuvo en su elaboración la Junta de Notables reunida en Bayona (cuyos miembros negaron repetidamente estar asumiendo funciones constituyentes) y que no vinculó en ningún caso al Emperador $y$, por otra parte, porque el texto aparece en su Preámbulo como emanado directamente de la voluntad regia, esto es, derivado del principio monárquico, con lo que el Estatuto no fundamentaría, sino tan sólo limitaría, el poder regio.

(*) Este trabajo forma parte de una tesis doctoral sobre La responsabilidad del Gobierno en la historia constitucional española, en curso de elaboración bajo la dirección del Profesor Doctor Joaquín Varela Suanzes, Catedrático de Derecho Constitucional de la Universidad de Oviedo.

1 Así, podemos señalar, entre otros, a los profesores Luis SÁnCHEz Agesta, Historia del constitucionalismo español, Instituto de Estudios Políticos, Madrid, 1974, donde, si bien menciona el texto, no lo incluye entre las Constituciones españolas decimonónicas; Joaquín TOMÁs VILLARROYA, Breve historia del constitucionalismo español, Centro de Estudios Constitucionales, Madrid, 1990; y Manuel MarTínez SospedRA, La Constitución de 1812 y el primer liberalismo español, Cátedra Fadrique Furió Ceriol, Valencia, 1978. 
El texto, claramente deudor de la Constitución francesa de Frimario del Año VIII ${ }^{2}$, descubre a lo largo de su articulado, confuso y contradictorio como fruto de las circunstancias que rodearon a su creación, un entramado orgánico que no oculta un régimen latentemente autoritario, en el que el Monarca se constituía como centro indiscutible del sistema.

Las competencias del titular de la Corona, ya estuvieran expresamente reconocidas por la Constitución, ya se entendieran implícitas en la prerrogativa regia al no serle sustraidas por ésta ${ }^{3}$, alcanzaban a todos los ámbitos del poder estatal, hasta el punto de subsumirlos. Era, sin duda, en la función legislativa donde esta tendencia monopolizadora alcanzaba su mayor relieve, puesto que en este campo la actuación de la Corona era decisiva. En primer lugar, ejercía funciones legislativas provisionales en tanto no se hallasen convocadas las Cortes. Esta competencia era tanto más relevante en cuanto podía el Monarca convocar y disolver las Cortes a su albedrío, lo que le permitiría legislar libremente sin su obstáculo. Además, puesto que éstas carecían de iniciativa legislativa, una vez reunidas, de no impulsar el Rey el procedimiento legislativo, la normativa provisional acabaría convirtiéndose de facto en definitiva.

En segundo lugar, era el órgano competente para abordar el desarrollo normativo constitucional. Esta facultad regia, recogida en el art. 143, suponía la ausencia de eficacia directa de la Constitución, requiriendo su presencia en la vida jurídica de la intermediación de normas emanadas del titular de la Corona.

Por último, y lo que es más importante, las leyes aparecían como normas emanadas de su voluntad, y no de las Cortes. Así se desprende del art. 86, donde se decía que "los decretos del Rey que se expidan a consecuencia de deliberación y aprobación de las Cortes se promulgarán con esta fórmula: "Oídas las Cortes"». Por consiguiente, se trataba de normas regias que adquirían fuerza de ley con el plus de la participación de las Cortes. Obsérvese al respecto la diferencia con el art. 37 de la Constitución de Frimario, donde se hablaba de "Tout décret du Corps législatifi.

2 Carlos Sanz CID, La Constitución de Bayona, Ed. Reus, Madrid, 1922, pág. 173. Para Artola, la vinculación habría que buscarla en el Senatus Consultus de 18 de mayo de 1804. Cfr. Miguel Artola, La Burguesía Revolucionaria (1808-1874), Alianza, Madrid, 1990, pág. 25.

3 En este sentido, la Constitución, como emanación del principio monárquico y simple limitación, se circunscribiria a reconocer los poderes regios, no a fundamentarlos. Por consiguiente, todo poder no sustraído por la Constitución al Monarca debe entenderse comprendido en su ámbito de potestad. 
El resto de órganos constitucionales estaban concebidos esencialmente como elementos de apoyo al Monarca. Por lo que respecta a los ministros, éstos eran meros agentes ejecutores de su voluntad, careciendo de identidad como gabinete ${ }^{4}$.

Se instituía también un Senado que, frente a lo particular de su nomen iuris, no puede concebirse como cámara legislativa ${ }^{5}$, sino como un órgano sui géneris de carácter esencialmente regio, que asumía dos tipos de funciones: por una parte, las referidas a la eficacia constitucional (suspensión de la Constitución en situaciones de crisis ${ }^{6} y$ declaración de inconstitucionalidad de actos de juntas electorales) ${ }^{7} y$, por otra parte, las referidas a la garantía de derechos legales (protección de la libertad de imprenta y la libertad personal frente a violaciones de las mismas $)^{8}$.

4 Se reconocía la responsabilidad individual de los ministros, al tiempo que se afirmaba que no habría más preferencia entre éstos que la antigüedad de su nombramiento (arts. 31 y 30 ). Es cierto, sin embargo, que en la práctica se modificaría esta situación, creándose un Consejo de Ministros y siendo frecuentes los Consejos Privados. Vid. Miguel ArtolA, Los Afrancesados, Ediciones Turner, Madrid, 1976, págs. 205 y ss.; Juan Mercader Riba, José Bonaparte, Rey de España (18081813), CSIC, Madrid, 1983, págs. 64 y ss.

5 La consideración del Senado de 1808 como cámara legislativa es frecuente entre nuestra doctrina. Así, Jorge DE EsTEBAN (director), Esquemas del Constitucionalismo Español (1808-1976), Facultad de Derecho de la Universidad Complutense, 1976, pág. 44; Antonio TORRES del Moral, Constitucionalismo Histórico Español, Átomo Ediciones, Madrid, 1986, pág. 30; Emilio ATTARD, El Constitucionalismo Español: 1808-1978, Valencia, 1988, pág. 51; Francisco Fernández Segado, Las Constituciones Históricas Españolas, ICAl, Madrid, 1982, pág. 61. Sin embargo, ya a mediados del siglo XIX, el Conde de Toreno percibió que, a pesar de su denominación, este órgano napoleónico encerraba una institución bien distinta. Vid. CONDE DE TOREno, Historia del Levantamiento, Guerra y Revolución de España, Atlas, Madrid, 1953, pág. 87.

${ }_{6}$ El artículo 38 del Estatuto, donde se contemplaba esta facultad del Senado, era una copia prácticamente literal del art. 92 de la Constitución francesa del año VIII, con la diferencia de que en ésta última la declaración de haber lugar a la suspensión debía hacerse por ley, en tanto que en la Constitución de Bayona le correspondía tal facultad al Senado, pero con la concurrencia del Monarca.

7 La Constitución Francesa del año Vill también preveía la declaración de inconstitucionalidad, si bien con carácter más amplio que la regulada en el Estatuto, puesto que podía afectar a todo tipo de actos, no sólo a los derivados de las Juntas de Elección (art. 21). Un precepto de idéntico contenido fue incluido en el primitivo proyecto del Estatuto de Bayona, pero no pasaría al texto que fue sometido a la Junta de Notables.

${ }^{8}$ La tutela en este caso no se refiere directamente a la Constitución, sino a derechos de configuración legal. La libertad de imprenta y la libertad personal aparecían, ciertamente, recogidas en la Constitución, pero para la primera se decía expresamente que debía ser regulada por ley dos años después de ejecutarse íntegramente la Constitución (art. 145), no siendo hasta entonces un derecho invocable, mientras que la libertad personal quedaba también sujeta al principio de legalidad 
Finalmente, también las Cortes se configuraban como un órgano de débil factura. Tenían un carácter estamental ${ }^{9} \mathrm{y}$ asumian funciones legislativas, presupuestarias y de control, pero las dos primeras quedaban matizadas $y$, hasta cierto punto, anuladas por el poder normativo regio, en tanto que la última, objeto de este trabajo, distaba de tener el preciso relieve como para que las Cortes se configurasen en un órgano imprescindible del sistema. Veámoslo.

\section{SUJETO PASIVO Y REGLA GENERAL DE RESPONSABILIDAD}

El primer aspecto a tener en cuenta es el del propio sujeto pasivo de la responsabilidad. Efectivamente, no se puede, sin más, hacer referencia a "responsabilidad del Gobierno", puesto que dentro del término "Gobierno" se incardinan una pluralidad de órganos, de manera que es preciso delimitar a quién va a alcanzar stricto sensu dicha responsabilidad. A este respecto, el profesor MENÉNDEZ REXACH, al analizar la configuración del Gobierno en la Constitución Francesa del Año VIII (que se reproduce en esencia en el Estatuto de Bayona), entiende que debe distinguirse entre "gobierno", propiamente dicho, que correspondería al Primer Cónsul asistido por el Consejo de Estado y "función ejecutiva", que correspondería a los ministros ${ }^{10}$.

De acuerdo con esta división, las líneas generales de la política gubernamental ("gobierno») serían establecidas por el Cónsul con la asis-

en sentido estricto, al establecerse en el art. 128 que nadie podia ser detenido sino por causas y personas establecidas por la ley. Por otra parte, las competencias atribuidas al Senado no hacían sino corroborar la posición omnipresente del Monarca, puesto que las relativas a la eficacia constitucional requerían de la iniciativa de éste para ser ejercidas, en tanto que las referidas a la tutela de derechos no eran por si eficaces, asumiendo el Rey la competencia decisoria última.

- No obstante, se introduce la importante novedad de la supresión de los privilegios (art. 118), recogiendo en cierta medida el ideario de Sieyes (Vid. Essai sur les Privilèges); un autor que tuvo una participación esencial en la elaboración de la Constitución francesa del Año VIII (Cfr. Yves Guchet, Histoire ConstitutionneIle Française (1789-1958), ERASME, París, 1990, pág. 129), principal fuente del Estatuto.

10 Ángel Menéndez Rexach, La Jefatura del Estado en el Derecho Público Español, INAP, Madrid, 1979, págs. 150 y ss. Se reconocía así la distinción trazada por Sieyes entre "pouvoir exécutif" y "pouvoir gouvernant", caracterizándose el primero por ser todo acción y el segundo por ser "toute pensée». Cfr. Jacques Godeснот, Les Institutions de la France, Presses Universitaires de France, París, 1968, pág. 554. 
tencia del Consejo de Estado, dedicándose los ministros a la mera ejecución automática de dichas directivas ${ }^{11}$. En consecuencia, aplicado este esquema al régimen de Bayona, el Gobierno en sentido amplio sería un órgano complejo, integrado por Rey, Consejo de Estado y ministros. Dentro de esta tríada, el sujeto pasivo de la responsabilidad se circunscribía a los ministros por razones obvias: por una parte, el Monarca era irresponsable e inviolable, mientras que, por lo que a los miembros del Consejo de Estado se refiere, desempeñaban funciones meramente consultivas.

Resulta asi que la responsabilidad del Gobierno se concentraba exclusivamente en los ministros, por lo que parece más apropiado hablar de responsabilidad ministerial. La consecuencia inmediata de esta perspectiva será la de afirmar la imposibilidad de control sobre los actos políticos del Gobierno, puesto que procedían de órganos esencialmente irresponsables, siendo tan sólo controlables los actos de ejecución de la política gubernamental, esto es, los actos jurídicos.

El Estatuto de Bayona recogía expresamente esta responsabilidad ministerial en su artículo 31: "Los Ministros, cada uno en la parte que le toca, serán responsables de la ejecución de las leyes y de las órdenes del Rey". La redacción parece dejar sentadas una serie de notas definitorias del sistema de responsabilidad que a continuación serán objeto de análisis.

\section{Regla general y responsabilidad jurídica. La figura del refrendo}

En primer lugar, parece afirmarse la idea ya expuesta de que la responsabilidad se centraría en actos de mera ejecución, o sea, actos jurídi$\cos y$, en este sentido, los ministros serían agentes de la potestad ejecutiva, potestad cuya titularidad, por otra parte, correspondía al Rey. La

"En un sentido amplio, el poder ejecutivo comprende tanto la ejecución propiamente dicha como una serie de facultades que conforman la función de dirección política. De esta manera, se produce una diferenciación de «dos esferas, la política y la jurídica, caracterizada ésta última por la plena sujeción a la ley y el control judicial" (Luis López Guerra, "La posición constitucional del Gobierno", en Gobierno y Administración en la Constitución, Instituto de Estudios Fiscales, Madrid, 1988, pág. 20). En el Estatuto de Bayona esta dualidad de esferas era aún más manifiesta al atribuirse cada una de ellas a órganos distintos y no a un único titular, como ocurría en otras monarquías limitadas: función directora al Rey asistido por el Consejo de Estado y función ejecutiva en sentido estricto atribuida a los ministros. 
responsabilidad se predicaba tanto de la ejecución de las leyes como de las órdenes del Rey, ahora bien, conforme a la teoría aquí defendida, se estaría en ambos casos, en realidad, ante una única vinculación de los ministros, a saber, la vinculación regia. Efectivamente, no sólo podían entenderse como agentes del Rey, ejecutores de su voluntad, en lo que a las órdenes del Rey se refiere, sino que en su papel ejecutor de la ley también asumían esta misma función de agentes del Monarca, toda vez que la ley era originariamente norma regia según se ha visto ${ }^{12}$.

Por consiguiente, Rey y Consejo de Estado (éste último con carácter exclusivamente consultivo) desempeñaban una función gubernativa, trazando las líneas generales de la política estatal a través de "órdenes del Rey", en sentido amplio, así como de "leyes", si bien éstas requerían también la participación de la asamblea popular. Por su parte, los ministros eran los encargados de ejecutar estas líneas políticas trazadas por los órganos de gobierno en sentido estricto.

Sin embargo, la determinación de la política estatal no era controlable, sino que la responsabilidad afectaba tan sólo a la ejecución de esa política. Siendo más concisos; como dice ENZO CHELI, la función de gobierno se manifiesta necesariamente a través de formas propias de otras funciones estatales ${ }^{13}$; en el caso que nos ocupa, la función directiva se plasmaba, en un primer momento, en las leyes y órdenes del Rey lo sea, en la función legislativa y la prerrogativa regia), que constituirían la positivación del indirizzo trazado por el órgano de gobierno. En un segundo momento, los ministros ejecutarían estas líneas políticas así normativizadas, de tal modo que la dirección general del Estado encontrase realización concreta en las situaciones ordinarias. De estos momentos, conforme al sistema de responsabilidad trazado por el Estatuto de Bayona, tan sólo el segundo era susceptible de control.

$12 \quad$ Vid. supra, pág. 2.

13 Enzo $\mathrm{CHEL}_{\mathrm{H}}$, Atto politico e funzione d'indirizzo politico, Giuffrè, Milano, 1961, págs. 68 y ss. En este sentido, el liberalismo doctrinario no llegó a concebir la función de gobierno como autónoma precisamente por el hecho de no contar ésta con actos y procedimientos propios a través de los cuales manifestarse. Cfr. Giuseppe Ferrarl, Corso istituzionale di Diritto Pubblico, Giuffrè, Milano, 1976, pág. 129. Vid. también al respecto Karl LoEWENSTEIN, Teoría de la Constitución, Ariel, Barcelona, 1970, págs. 61 y ss. La misma opinión puede verse en MorTATI, para quien la dificultad de clasificar esta función entre las clásicas funciones estatales se debería a que "operi no gia con atti tipici e seguendo forme tipiche, sempre uguali, ma mettendo in essere atti e procedimenti di differente natura, secondo la qualità degli interventi ad essa richiesti, corrispondenti, nella loro varietà, alle finalità della funzione stessa». Vid. Costantino MortatI, Istituzioni di Diritto Pubblico, vol. II, CEDAM, Padova, 1969, págs. 602 y ss. 
Como consecuencia, se hacía en última instancia responsables a los ministros por la dirección política del Estado trazada por otro órgano, jerárquicamente superior: el Rey. Lo que se producía, en definitiva, no era sino un traslado de responsabilidad (pero no de función) desde el Rey hasta sus ministros ejecutores. Esta transposición se verificaba no sólo mediante el reconocimiento expreso de la responsabilidad de los ministros por la ejecución de leyes y órdenes regias, sino también a través de la figura del refrendo, que recogía el art. 28 de la siguiente manera: "Un Secretario de Estado, con la calidad de Ministro, refrendará todos los decretos".

El Estatuto de Bayona es un claro ejemplo de la primera concepción que históricamente ha desempeñado el refrendo: traspaso de la responsabilidad, pero no de la función. En ningún caso se puede decir que el refrendo supusiese vaciar el ejercicio de las competencias regias y su consiguiente absorción por los ministros. Por el contrario, del entramado orgánico se derivaba que el titular de la Corona aparecía como el auténtico adalid del sistema, asumiendo un papel claramente activo y decisorio, de manera que los ministros quedaban relegados al papel de meros agentes regios ejecutores de competencias que en ningún caso ejercian.

La atribución de la responsabilidad a sujetos no ejercientes de la función que origina ésta no puede sino plantear problemas teóricos que la doctrina trató de solventar frecuentemente, en un estadio inicial, a través de lo que podemos llamar "responsabilidad por influencia". Conforme a esta postura, el Rey no podía querer el mal («King can do no wrong") y era, pues, irresponsable. Por lo tanto, la explicación de posibles actos injustos del Monarca sería el mal consejo o la mala influencia ejercida por sus ministros, que eran, así, los responsables del acto finalmente ilegítimo.

Esta teoría, importada de MONTESQUIEU ${ }^{14}$, y que mantendrá en la doctrina española años más tarde RAMÓN SALAS ${ }^{15}$, se perfila tenuemente dentro de la Junta de Bayona en el diputado ALCALÁ GALIANO ${ }^{16}$,

14 "Como el que ejecuta no puede ejecutar mal sin tener malos consejeros que odien las leyes como ministros, aunque éstas les favorezcan como hombres, se les puede buscar y castigar" (Montesquieu, Del Espíritu de las Leyes, Libro XI, Capítulo VI).

15 Ramón Salas, Lecciones de Derecho Público Constitucional (1821), Centro de Estudios Constitucionales, Madrid, 1982, Lección XXI, pág. 138.

${ }^{16}$ El profesor Antonio Elorza ha estudiado el ideario de este autor, tío de quien fuera uno de los más importantes representantes del liberalismo moderado del siglo XIX, y en cuya formación ilustrada destaca la influencia de los clásicos 
muy en conformidad con el sentimiento de recelo hacia los ministros que era común en la época; recelo del que la figura de Godoy había sido, sin duda alguna, principal responsable. En este sentido, apuntaba este diputado: "Tengo muy presentes los males que se han experimentado en España por el mayor influjo de alguno de los Ministros (...). El Soberano no junta las Cortes, si así conviene a las miras de sus favoritos o privados" ${ }^{17}$.

Sin embargo, aunque tanto la responsabilidad por la ejecución de leyes y órdenes del Rey como el refrendo de los decretos expresaban un movimiento traslativo de responsabilidad del Monarca como órgano de gobierno a los ministros como ejecutores, lo cierto es que, tal y como se manifestaba la regulación de la Constitución de Bayona, había un importante matiz diferenciador de ambos. En efecto, si bien la responsabilidad por la ejecución de leyes y órdenes se afirmaba de los ministros, el refrendo correspondía exclusivamente al Secretario de Estado. Quiere esto decir que respecto a los primeros actos jurídicos cualquier ministro podía ser responsable, mientras que respecto a los segundos sólo cabía la responsabilidad del Secretario de Estado que, al refrendarlos, se había hecho acreedor de la misma.

\section{Regla general y responsabilidad individual}

El segundo aspecto que podemos inferir de la regla general de responsabilidad ministerial establecida en el art. 31 del Estatuto es el de la responsabilidad individual.

Ya se ha comprobado cómo del articulado no se deducía una estructura colegiada de los ministros, con lo cual aparecían éstos directamente como órganos constitucionales, sin mediar la presencia de un Consejo de Ministros en el que se integrasen como órganos. Por esta razón, la función de ejecución de las leyes y órdenes regias era asumida individualmente, ejecutando cada ministro aquellas disposiciones que afectaban a su ramo de la administración. No podía, por ende, predicar-

franceses como Mably y Rousseau. Cfr. Antonio Elorza, La ideología liberal en la ilustración española, Tecnos, Madrid, 1970, págs. 173 y ss.

${ }_{17}$ Observación de 25 de junio de 1808. Las actas de la Junta, así como las observaciones particulares de sus miembros citados en el presente trabajo, se encuentran el el volumen Actas de la Diputación General de Españoles que se juntó en Bayona el 15 de junio de 1808, Imprenta y Fundición de J. A. García, Madrid, 1874. 
se ningún tipo de coordinación interministerial: cada ministro era independiente en su departamento. Esta absoluta disociación no generaba, sin embargo, la disgregación de la unidad de la política estatal, puesto que dicha unidad quedaba garantizada al ser un órgano superior y unipersonal quien determinaba la misma; la heterogeneidad se manifestaba en la ejecución, no en la dirección política, que-continuaba siendo unitaria $^{18}$.

El carácter individual de los ministros suponía, por tanto, la exigencia de responsabilidad a cada uno de ellos separadamente por las actuaciones ilegítimas realizadas en la ejecución de leyes y órdenes regias que correspondía a su ramo de administración.

Conclusión: de la regla general de responsabilidad se inferían, prima facie, dos principios: responsabilidad uti singulis o individual de los ministros y responsabilidad por actos de ejecución de leyes y órdenes regias, así como por los decretos del Rey (en este último caso responsabilidad exclusiva del Secretario de Estado refrendante).

\section{SUJETOS ACTIVOS DE LA RESPONSABILIDAD: LAS CORTES}

Delimitado sobre quién se hacía efectiva la responsabilidad, corresponde ahora analizar los órganos que asumían la función de control y exigencia de dicha responsabilidad. En este sentido, una de las particularidades principales del Estatuto estribaba en la existencia de una pluralidad de órganos controladores. Concretamente, se puede diferenciar entre órganos competentes para controlar la acción del ejecutivo y exigir responsabilidad y órganos ante quienes se hace efectiva dicha responsabilidad.

Para evitar que de la ejecución ministerial pudieran resultar abusos, el Estatuto contemplaba la sujeción a dos órganos controlantes, Cortes y Senado, quienes desempeñaban esta función en íntima relación con las otras competencias que les correspondían (presupuestaria y legislativa en el caso de las Cortes, y de defensa de derechos y libertades por lo que al Senado respecta). Cuando del control ejercido sobre los ministros

18 Sobre la necesidad de una dirección unitaria del Estado, vid. Georg JELLINEK, Teoria del Estado, Albatros, Buenos Aires, 1978, págs. 419 y ss. Vid. también Carré de Malberg, Teoría General del Estado, Fondo de Cultura Económica, México, 1948 , págs. 789 y ss. 
resultaba evidente una infracción (jurídica, como veremos), ambos órganos estaban facultados para reclamar responsabilidades ante otras instancias (el segundo grupo de órganos) que las hacían efectivas.

\section{Problemática de la legitimación de las Cortes como órgano de control}

La posibilidad de las Cortes de reprobar la conducta ministerial se plasmaba en el art. 85 del texto: "En caso de que las Cortes tengan que manifestar quejas graves y motivadas sobre la conducta de un ministro, la representación que contenga estas quejas y la exposición de sus fundamentos, votada que sea, será presentada al Trono por una diputación".

Ahora bien, el primer problema que se plantea es el de justificar en qué medida las Cortes eran un órgano legítimo para dicha tarea. La cuestión puede resultar en principio extraña, ya que han sido y son, tradicionalmente, las Cortes quienes ejercen la función controladora y de exigencia de responsabilidad del ejecutivo. Sin embargo, el particular carácter de la asamblea representativa en el texto de Bayona y su posición constitucional "secundaria" alteran esta realidad.

El fundamento del control del legislador sobre el ejecutivo se encuentra históricamente y de forma generalizada en dos razones, ya sea alternativa o conjuntamente: por una parte, en la preeminencia y preexistencia de la ley sobre el momento ejecutivo. Según esta concepción, la ley sería el presupuesto de la potestad ejecutiva, que no encontraría razón de existencia faltando la primera; la ley, por tanto, preexiste a la ejecución, lo cual le proporcionaría ya una cierta nota de superioridad. Por esta misma razón, el órgano legislativo, en cuanto productor de la norma, ha de ser también competente para revisar cómo se ejecuta ésta, lo que conllevaría también la retención de la potestad interpretativa por el autor de la ley (interpretación auténtica). La justificación del control de la Asam-

19 Ésta es la postura que mantiene Montesouieu: «Pero si en un Estado libre el poder legislativo no debe tener derecho a frenar al poder ejecutivo, tiene, sin embargo, el derecho y debe tener la facultad de examinar cómo son cumplidas las leyes que ha promulgadon. Montesquieu, Del Espíritu de las Leyes, Libro XI, Capítulo VI. Sin embargo, el control sobre el ejecutivo no legitima, en MonTesouieu, la posibilidad de juzgar su actuación cuando del control resulte una conducta negativa (ídem). 
blea sobre el ejecutivo sería, por lo tanto, de carácter normativo-interpretativo ${ }^{19}$.

La segunda fundamentación a la facultad controladora del legislativo se encontraría en el principio de soberanía nacional o popular ${ }^{20}$. En efecto, la atribución de la soberanía a la colectividad (ya sea pueblo o nación) conllevó en la teoría liberal la superioridad del órgano que legítimamente asumia su representación, el Parlamento, e incluso, en algunos supuestos, se llegó a afirmar no ya la superioridad, sino incluso la soberanía del Parlamento, fruto de una hipostación Cortes/Nación. Esta superioridad del órgano legislativo, que ya se vislumbraba en LOCKE y BLACKSTONE, estaba ligada al principio representativo, por cuanto la Nación, al no poder actuar por si misma, lo hacía por medio de las personas que elegía. La consecuencia es, como dice CARRÉ DE MALBERG, que "el representante posea los mismos poderes que si fuera personalmente soberano. Indudablemente, no posee él mismo la soberanía, que sólo pertenece a la nación (...). Pero al representar al soberano, toma de éste su poder de decisión soberana" ${ }^{21}$. De esta manera, si bien la Nación era titular de la soberanía, su ejercicio correspondia a la asamblea de representantes ${ }^{22} y$, como conclusión lógica, se llegaba a la idea de que al poder soberano de la nación se correspondia un poder "supremo" de la asamblea que la representaba. Por esta razón, el Parlamento no ostentaba una posición paritaria al resto de órganos constitucionales, sino de supremacía sobre éstos ${ }^{23}$. Tal encuadre constitucional de la Asamblea explicaría su facultad de controlar la acción de un órgano ejecutivo que se hallaba subordinado ${ }^{24}$. En esta construcción, el Parlamento utiliza el control como instrumento para modificar el rumbo de la acción ejecutiva, e incluso gubernativa, adecuándola a la

20 Vid. al respecto Joaquín Varela SuAnzes, "Algunas reflexiones sobre la Soberania Popular en la Constitución Españolan, Revista Española de Derecho Constitucional, núm. 36, 1992, págs. 71 y ss.

${ }^{21}$ CarRÉ De MaLBerg, Teoría..., op. cit., pág. 922 y ss.

22 Ignacio DE OTTO, Lecciones de Derecho Constitucional, Universidad de Oviedo, 1985, pág. 267. Consúltese también Joaquín Varela Suanzes, La Teoría del Estado en los Orígenes del Constitucionalismo Hispánico (Las Cortes de Cádiz), Centro de Estudios Constitucionales, Madrid, 1983, págs. 279 y ss.

${ }^{23}$ Así, como afirma Ignacio de Otto, para esta postura doctrinal "sólo el Parlamento tiene, en su calidad de representante del soberano, un poder originario, mientras que los demás órganos del Estado son únicamente "agentes" o "funcionarios" que actúan con poderes derivados, que proceden de la ley, de la voluntad general». Cfr. Ignacio DE OTTO, Derecho Constitucional. Sistema de Fuentes, Ariel, Barcelona, 1988, pág. 136.

${ }^{24}$ En este sentido, el control no presentaba una de las características que en la actualidad se predican de los controles constitucionales, como es la ausencia de relación jerárquica entre controlante y controlado. Vid. Serio Galeotri, Introduzione alla Teoria dei Controlli Costituzionali, Giuffrè, Milano, 1963, págs. 13 y ss. 
voluntad nacional que representa: puesto que dicha voluntad es soberana, es el Parlamento, en cuanto representante de la misma, quien asume $o$, al menos, participa en la función de gobierno, de manera que toda acción del ejecutivo tendrá que acomodarse a la voluntad de la nación, cuyo intérprete legítimo es el Parlamento ${ }^{25}$.

Si se trasladan ambas fundamentaciones a la estructura de la Constitución de Bayona, puede comprobarse cómo ninguna de ellas sirve para justificar el poder de control de las Cortes estatuarias sobre los ministros. Así, el primer criterio legitimador, la preexistencia y preeminencia de la ley, no puede esgrimirse, ya que, si bien es cierto que la ley precede a la ejecución, en realidad, en la Carta de Bayona, esta norma es originariamente de procedencia regia. De esta manera, teniendo las Cortes una participación en extremo exigua en la potestad legislativa ${ }^{26}$, no parece muy justificado que sea precisamente este órgano quien asuma la defensa de la correcta ejecución de una ley que en esencia no es emanación suya. La atomización y fragmentación del poder legislativo en una pluralidad de órganos, característica del ideario napoleónico, podría en parte dificultar la ubicación de la ley en un órgano concreto, pero de hacerlo será en el Monarca y no en las Cortes ${ }^{27}$.

25 Así, "en su principio, el control ejercido por el Parlamento sobre el Gobierno responde a una idea simple, lógica y práctica. Desde el momento en que los elegidos por el pueblo encarnan su voluntad, deben vigilar la manera en que se conduce la política del Estado, para mantenerla en la línea que corresponde a lo deseado por la colectividad nacional". Cfr. Georges Burdeau, Traité de Science Politique, Librairie Générale de Droit et de Jurisprudence, París, 1976, vol. IX, pág. 393. En este mismo sentido se había pronunciado Stuart Mill en 1865: "Gobierno representativo significa que la nación, o al menos una porción numerosa de ella, ejerza, por medio de diputados que nombra periódicamente, el poder supremo de inspección e intervención". Cfr. John StUART MILL, Gobierno representativo (1865), Tecnos, Madrid, 1965, pág. 200.

${ }_{26}$ Respecto al papel limitado que desempeñan las asambleas en las constituciones napoleónicas, cfr. André Hauriou, Droit Constitutionnel et Institutions Politiques, Editions Montchrestien, París, 1970, pág. 693: "Le Pouvoir législatif n'est pas supprimé, mais il est rendu muet. Les Assemblèes législatives sont, par nature, un théatre de discussions".

${ }^{27}$ Sin embargo, no resulta difícil atribuir en el Estatuto de Bayona la ley a un órgano concreto. Es cierto que hay una relativa dispersión del poder legislativo, como afirma el profesor Fernández Segado (Francisco Fernández SEgado, Las Constituciones..., op. cit., pág. 61), pero ésta es más una característica de la Constitución francesa del año VIII (en la que, además de los órganos legislativos que aparecen en Bayona, hay que sumar el Tribunal) que del Estatuto de 1808. Sobre la dispersión de la potestad legislativa en las Constituciones Napoleónicas vid. Maurice DESLANDRES, Histoire Constitutionnelle de la France, vol. I, Edouard Duchemin, París, 1977, págs. 451 y ss; Ángel Menéndez ReXACH, La Jefatura..., op. cit., pág. 153, y Karl LOEWENSTEIN, Teoría..., op. cit., pág. 84. 
Tampoco la segunda razón apuntada puede predicarse de las Cortes de Bayona: no existía soberanía nacional, luego las Cortes no ostentaban posición suprema alguna; soberano lo era solamente el Rey y el resto de órganos se hallaban manifiestamente subordinados a él. Las Cortes no podrían acudir a una hipotética situación de sometimiento de los ministros a la Asamblea para justificar el control que ejercían, puesto que tal subordinación no se daba en la realidad; aquéllos eran agentes ejecutivos de un monarca soberano y ésta constituía la representación por estamentos de un pueblo de quien no se reconocía la soberanía.

Si se aduce que mediante el control se trataria de buscar un equilibrio constitucional, es preciso recordar que las Cortes no encarnaban la potestad legislativa, sino que eran meros partícipes en la misma.

En definitiva, el texto de Bayona se recubría en este aspecto de una patente oscuridad, fruto de un origen tan coyuntural como exento de sólida elaboración doctrinal. Como en otros aspectos, en él se mezclaban reminiscencias propias de la soberanía nacional, que se proclamó en la Constitución francesa de 1791, con una clara tendencia a centralizar el poder en manos del monarca. El resultado fue un texto abigarrado, en el que las instituciones, como la propia del control, no ensamblaban entre sí, generando un ordenamiento bastante poco armónico. No cabe duda de que en las constituciones donde la proclamación de la soberanía nacional hace acto de presencia, el control del Parlamento sobre el ejecutivo encuentra clara justificación. Lo mismo puede decirse de aquellas otras en las que la soberanía se halla dividida entre el Rey y la nación (en este caso primaría la idea de equilibrio para fundamentar el control). Sin embargo, en el Estatuto, el egocentrismo monárquico trataba de combinarse con la pervivencia de funciones tradicionales del Parlamento (como la de control) que, en realidad, pasaban a ser difícilmente justificables al hallarse ahora este órgano desnaturalizado.

\section{Los medios de control del ejecutivo}

Si bien es cierto que el poder de control de las Cortes sobre los ministros encuentra una difícil justificación teórica, también lo es que era en esencia débil y difuso. En este sentido, es evidente que la exigencia de responsabilidad que el art. 85 reconocía a las Cortes implicaba necesariamente una previa fiscalización sobre el ejecutivo, pero, sin embargo, el texto omitía mecanismos concretos de control, con la salvedad que a continuación veremos. 
En efecto, frente a otros textos constitucionales posteriores que establecerán la posibilidad de plantear preguntas, interpelaciones, peticiones $u$ otros mecanismos semejantes, a través de los cuales se podía efectuar un control, el Estatuto de Bayona carecía de tales previsiones. Por esta razón, podría llegarse a la antinomia de que las Cortes estaban facultadas para controlar la actividad ministerial, pero carecían, al mismo tiempo, de instrumentos para llevarlo a cabo $y$, más específicamente, de medios de inspección a través de los cuales poder informarse de dicha actividad ministerial. En este apartado, sin embargo, el Estatuto no dejaba de seguir la tónica general que presidía la práctica totalidad de su articulado, es decir, la oscuridad de sus preceptos y la constante presencia de lagunas.

El artículo 84 del Estatuto, no obstante, sí introducía un medio de control, el único que reconocía el texto de Bayona a las Cortes. De acuerdo con el mismo, el ministro de Hacienda debía comparecer ante la asamblea para presentar "las cuentas de Hacienda, dadas por cargo y data, con distinción del ejercicio de cada año", y las Cortes "podrán hacer, sobre los abusos introducidos en la administración, las representaciones que juzguen convenientes". En este aspecto sí que muestra el articulado una congruencia que constituye, como queda señalado, mucho más la excepción que la regla general. Efectivamente, el único instrumento de control de que disponian las Cortes aparecía ligado a una función específica y relevante de las mismas: la aprobación de los presupuestos del Estado. Ello obligaría a reinterpretar la oscuridad respecto a los mecanismos de control. De esta manera, pudiera entenderse que en realidad lo que se pretendía era atribuir a las Cortes un único mecanismo de control que cohonestara con la que, quizás, fuera su función principal: la presupuestaria. Sin embargo, no por adoptar esta solución se evita la conflictividad de la regulación, puesto que nos llevaría a afirmar que las Cortes se ceñirian, en atención al instrumento de control, a exigir responsabilidades sólo por infracciones de carácter presupuestario, ya que son éstas principalmente (aunque no en exclusiva, es cierto) las que serían conocidas y contrastadas mediante el mecanismo controlante que reconoce el citado art. 84. Quedaría así diluida la responsabilidad que reconocía la regla general, es decir, la responsabilidad de los ministros por ejecución de las leyes y órdenes (así como la del refrendante por los decretos refrendados), de forma que sólo serian responsables por las infracciones que cometieran respecto a los ingresos y gastos públicos ${ }^{28}$.

28 Para evitar esta contradicción sólo cabe afirmar que el art. 84 y el art. 85 contenían dos tipos distintos de "representaciones», la del segundo artículo más amplia y compresiva de la primera. Así, la "representación" que recoge el art. 85 podía tener por objeto, evidentemente, un abuso introducido por la administración 
Sea como fuere, habida cuenta de que la ratio legislatoris se nos escapa al no disponer de información suficiente en las Actas de la Junta, lo cierto es que el Estatuto sólo reconocía este medio de control a las Cortes. La mayor importancia que presenta el mismo es que, como ha señalado el profesor Tomás Villarroya, "las Asambleas representativas se han servido de la discusión del Presupuesto para examinar la actuación seguida por los distintos ramos de la Administración y la política general del Gobierno" ${ }^{29}$. La escasa vigencia del Estatuto impide corroborar si esta afirmación es válida en el caso que nos ocupa, esto es, si las prácticas parlamentarias desviarían la finalidad teórica de este instrumento de control (la fiscalización de la actividad presupuestaria) hacia una función más amplia, la de un enjuiciamiento más extenso de la acción ministerial. De ser así, la dificultad teórica que hemos planteado de contar con este único mecanismo controlante se vería superada por la praxis.

\section{Naturaleza de la responsabilidad: La responsabilidad jurídica}

En los dos epígrafes anteriores hemos analizado la legitimación de las Cortes para enjuiciar la actividad de los ministros ( $y$, en su caso, exigirles responsabilidad), y los medios de control con que contaban para ejercer esa función de fiscalización. Toca ahora ocuparse de la exigencia de responsabilidad.

Para abordar esta cuestión dividiremos la exposición en dos momentos distintos: por una parte trataremos la forma en la que las Cortes exigían esa responsabilidad, o sea, solicitaban la adopción de sanciones sobre el sujeto responsable, o lo acusaban, si quiere utilizarse esta expresión. A continuación veremos qué órgano haría efectiva la responsabilidad, sancionando en su caso al ministro.

Esta diferenciación se hace precisa toda vez que, frente a lo que sucede en el parlamentarismo actual en el que las Cortes cuentan con instrumentos de exigencia de responsabilidad (moción de censura) que con-

en relación con las cuentas estatales, en cuyo caso ambos artículos hacian referencia a un idéntico documento. Sin embargo, también podia tener por objeto cualquier otra infracción ministerial de leyes y órdenes regias. Sólo así podía salvarse la congruencia con la regla general de responsabilidad reconocida en el art. 31.

${ }^{29}$ Joaquín TOMÁs Villarroya, "Los orígenes del control parlamentario en España", Revista de Estudios Políticos, núm. 132, págs. 114 y ss. 
llevan la sanción directa constitucionalmente reglada (de prosperar la moción, el presidente del Gobierno tiene que presentar su dimisión), en el período que aquí se estudia ambos momentos se hallaban inicialmente separados, fruto, esencialmente, de la doble confianza que asistía a los ministros.

Como hemos venido comprobando a lo largo de la exposición, el art. 85 del Estatuto de Bayona reconocía, aunque en términos generales e imprecisos, la posibilidad de las Cortes de exigir responsabilidad a los ministros cuando hubiera motivos de queja sobre su actuación.

Ahora bien, este artículo no debe interpretarse aisladamente, sino dentro del ámbito del art. 31, que contiene la regla general de responsabilidad y que, recuérdese, establecía que "los ministros, cada uno en la parte que le toca, serán responsables de la ejecución de las leyes y de las órdenes del Rey".

La interpretación sistemática de ambos preceptos proporciona los datos necesarios para afrontar la primera cuestión a tratar: la naturaleza de la responsabilidad en el Estatuto de Bayona.

Este problema constituye en gran medida el aspecto nuclear del concepto de responsabilidad; la diferenciación entre responsabilidad jurídica y política fue una constante en la doctrina y las prácticas parlamentarias decimonónicas. Inicialmente sólo se planteó el problema de la responsabilidad jurídica, desconociéndose la segunda por diversas razones, entre las que ocupa lugar preeminente la propia concepción tripartita de poderes y la no percepción de una cuarta función, la función de gobierno. Es así notorio cómo el tránsito de una concepción meramente jurídica de la responsabilidad a otra política corre paralelo al progresivo reconocimiento en la vida estatal de un ámbito de actuación discrecional que es preciso limitar ${ }^{30}$.

Por lo que respecta a esta cuestión en la Constitución de Bayona, el punto clave vendría dado por el hecho de que las Cortes podían manifestar quejas sobre la conducta de un ministro resultante del ejercicio de funciones ejecutivas, y, por lo tanto, nos hallamos ante un supuesto de

30 En este sentido, merece la pena recordar la afirmación del profesor Sánchez Agesta de que el fin de la responsabilidad política será «limitar el arbitrio que es connatural a la acción de gobierno". Cfr. Luis SÁnCHEZ AgESTA, "Gobierno y responsabilidad", Revista de Estudios Políticos, núm. 113-114, 1960, págs. 40 y ss. Sin embargo, lo que caracteriza a la función gubernativa no es el "arbitrio», que en ningún caso es permitido, sino la "discrecionalidad". 
regulación de responsabilidad jurídica. Los fundamentos serían los siguientes: en primer lugar, el art. 31, que establecía la regla general de responsabilidad, decía que los ministros serían responsables por la ejecución de las leyes y órdenes del Rey.

Por otra parte, como hemos visto, la actividad ministerial se circunscribía a esa función meramente ejecutiva de la política general trazada por el Rey en cuanto órgano de gobierno.

Por último, los parámetros utilizados por las Cortes para enjuiciar la actividad ministerial serían, por lo tanto, normativos (las leyes y órdenes del rey ejecutadas por los ministros) y no de oportunidad.

Parece claro que, no reconociendo a los ministros un ámbito de actuación política libre y discrecional, sino exclusivamente ejecutiva, sólo por la misma cabría exigirles responsabilidad. Como se ha señalado al tratar la cuestión del sujeto pasivo de la responsabilidad, se producia así una consecuencia adversativa: no aparecía como responsable quien tomaba libremente la decisión (el Rey asesorado por el Consejo de Estado), sino quien estaba obligado a ejecutarla (los ministros) y ello a pesar de que la ordenación jerárquica de sujeción al Rey le obligaba a proceder a tal ejecución. Por lo tanto, sólo los actos ejecutivos ilícitos eran atacables, nunca las decisiones políticas tomadas por los órganos gubernamentales, puesto que gozaban de inmunidad.

Por otra parte, en este tema hay una clara disociación de la regulación estatuaria con la plasmada en la Constitución francesa del año VIII, que era bastante más concisa y completa al respecto. Así, la responsabilidad de los ministros en el texto francés comprendia los actos contrarios a la Constitución, la inejecución de leyes y reglamentos y, finalmente, órdenes particulares procedentes de los propios ministros y que fueran contrarias a la Constitución, ley o reglamentos (art. 72). La regulación contemplaba, a diferencia de la articulada en la Constitución de Bayona, por una parte, actos de omisión (inejecución) y, por otra, infracciones constitucionales, con lo que se deriva una eficacia normativa directa de la Constitución.

En lo que respecta al debate doctrinal que se sostuvo en el seno de la Junta de Bayona, el tratamiento de la responsabilidad fue, como en casi todos (por no decir todos) los demás aspectos, extremadamente pobre $^{31}$. De las escasísimas intervenciones que nada aportan a la letra del

${ }^{31}$ No sólo las intervenciones fueron muy escasas (apenas figuran tres en las Actas), sino que además había quien consideraba que la regulación del Estatu- 
texto, merece la pena destacar, respecto al tema de la naturaleza de la responsabilidad, tan sólo la del diputado PEREYRA. Para éste, el artículo 31 , en el que se establecía, recuérdese, la regla general de responsabilidad, debía modificarse, con el objeto de conferirle mayor precisión y de alterar los términos en los que se fijaba la responsabilidad ministerial: "Dóime, por tanto, a entender que su responsabilidad debiera ser la misma que en Inglaterra, en cuyo supuesto pudiera concebirse así este artículo: Cada Ministro será responsable de las órdenes que expidiere contrarias a las leyesı ${ }^{32}$.

La referencia al sistema inglés pone de manifiesto el desconocimiento de la realidad política de la isla que, en esos momentos, era muy distinta de la continental. Así, mientras que el diputado PEREYRA predicaba una responsabilidad juridica, en Inglaterra las convenciones habian ido alterando ésta, haciéndola evolucionar hacia una responsabilidad política que ya se encontraba vigente en el momento en que se discute en Bayona el Estatuto, con lo cual la remisión al ordenamiento inglés no era acertada. Frente a lo que sucedía en la Constitución de Bayona, en la que los ministros aparecían como órganos puramente ejecutores de la voluntad regia, en Inglaterra los ministros habian logrado autonomía respecto a la Corona, de manera que las decisiones políticas eran en esos momentos adoptadas por el Gabinete, mientras el Monarca era relegado a una intervención formal ${ }^{33}$. De esta forma, en Inglaterra el traspaso de responsabilidad del Monarca a los ministros ya había acarreado un correlativo traslado de la propia competencia decisoria ${ }^{34}$. Bien es cierto que los

to al respecto del tema era suficiente. Así lo apuntaban los diputados ArRiBas y Gómez HeRmosilla, para quienes «acerca de la responsabilidad de los ministros se dice algo, y acaso lo bastante en el proyecto" (Observación de 26 de junio de 1808).

${ }_{32}$ Observación de 28 de junio de 1808.

33 Ivor Jennings, El Régimen Político de la Gran Bretaña, Tecnos, Madrid, 1962, págs. 35 y 62 . Debe destacarse que, a pesar de la progresiva y "dramática" reducción del papel político del Monarca en Inglaterra, ésta fue fruto no ya de crisis o declaraciones formales, sino de una evolución operada a lo largo de los años. Cfr. A.H. BIRCH, The British System of Government, George Allen \& Unwin Ltd., London, 1975, pág. 65. En gran medida, como señalaría Anson en 1892, la captación del rol activo por el Gabinete inglés, y la consiguiente relegación de la Corona, se debió a la tendencia de los Monarcas posteriores a la Reina Ana de no acudir a sus sesiones. Cfr. William R. Anson, The Law and Custom of the Constitution. Part II: The Crown (1892), Oxford at the Clarendon Press, pág. 37.; vid. también al respecto John P. Mackintosh, The British Cabinet, Stevens \& Sons Límited, London, 1977, págs. 49 y ss., donde narra pormenorizadamente la captación de facultades políticas a partir de la Reina Ana por el "Inner Cabinet" (o Gabinete en sentido estricto), en detrimento del "Full Cabinet" (o "Privy Council»).

${ }^{34}$ La máxima "the King can do not wrong", complementada con el también tradicional principio de que "the King can do not act alone», supusieron la progresiva captación en la práctica por los ministros de las funciones de la Corona (cfr. 
textos constitucionales británicos no habían sufrido alteración en lo que respecta a la responsabilidad ${ }^{35} \mathrm{y}$, en este sentido, podrían ser acertadas las palabras del diputado de la Junta de Bayona, puesto que la responsabilidad teórica de los ministros en Inglaterra era exigida por actos ilegales; sin embargo, la realidad constitucional era muy diferente, toda vez que las convenciones habían alterado el primitivo significado del instrumento para exigir la responsabilidad penal («impeachment"), de forma que éste era utilizado para dirimir conductas políticas no ilegales ${ }^{36}$.

Paolo BISCARETTI DI RufFIA, Introducción al Derecho Constitucional Comparado, Fondo de Cultura Económica, México, 1972, pág. 110; vid. WADE/PHILliPS, Constitutional Law, Longmans, Green and Co., London, 1934, págs. 73 y ss., donde especifica la alteración de la prerrogativa regia por las prácticas constitucionales y el ejercicio del poder regio por los ministros). De esta manera, la voluntad del monarca sufre una progresiva postergación, a medida que, por otra parte, la figura del Primer Ministro cobra cada vez más relevancia en el Gabinete (Cfr. F.W. MaITLANo, The Constitutional History of England, Cambridge at the University Press, 1931, págs. 397 y ss.; Ivor JeNNINGs, El Régimen..., op. cit., pág. 36). El monarca pasaría a mantener tan sólo en teoría aquellas funciones que derivaban del "common law" (prerrogativa) o de los "statutes" (cfr. Manuel Garcia Pelayo, "Derecho Constitucional Comparado", Revista de Occidente, Madrid, 1951, págs. 274 y ss.; F. W. MaItLAND, The Constitutional..., op. cit., pág. 399). Como reconocería Walter Bagehot en 1867, los ministros ejercerian, por lo tanto, la función gubernativa que antes le correspondía al Monarca, de manera que a éste tan sólo le asistiria el derecho "to be consulted, to encourage, to worn" (Walter BAGEHOT, The English Constitution (1867), Fontana Press, 1993, pág. 113).

35 Las modificaciones legales de la responsabilidad en Gran Bretaña son escasas; cabe destacar la "Grand Remonstrance" de 22 de noviembre de 1641, en la que ya se apunta la idea de que los ministros han de contar con la aquiescencia de las Cámaras y de que existen actos de estos ministros susceptibles de generar responsabilidad pero que no constituyen realmente infracciones penales, con lo cual se evidenciaba la insuficiencia del impeachment (Cfr. J. R. TANNER, English Constitutional Conflicts of the Seventeenth Century (1603-1689), Cambridge at the University Press, 1966, pág. 110; Manuel García Pelayo, Derecho Constitucional..., op. cit., pág. 246; para Chrimes este documento no era otra cosa que una pieza de propaganda del partido puritano antimonárquico, cfr. S. B. CHRIMES, English Constitutional History, Oxford University Press, London, 1967, pág. 112). Otra modificación normativa la constituye el "Act of Settlement", de 12 de junio de 1701, en cuyo apartado III, número 8. estipula que "Ningún perdón podrá lograrse, bajo el gran sello de Inglaterra, contra la acusación (impeachment) decidida por los comunes".

${ }^{36}$ Desde la dimisión de Walpole en 1742 se hace evidente que la responsabilidad penal de los ministros ante los Comunes pasa a convertirse en responsabilidad política, paralelamente al desarrollo de la idea de que el gabinete se sostenía con la confianza de los Comunes. Así lo había delimitado en 1739 el propio Walpole: "When I speak here as a minister, I speak as possessing my powers from his Majesty, but as being answerable to this House for the exercise of these powers". Cfr. A.H. BıRCH, "Responsibility in British Politics", en Ministerial Responsibility, Oxford University Press, 1989, pág. 27. La obsolescencia del impeachment como instrumento de exigencia de responsabilidad y su correlativa desviación, ya 


\section{Naturaleza de la responsabilidad: hacia una responsabilidad política}

Aparte de esta intervención, mediante la cual se comprueba cómo este diputado coincidía con el Estatuto al entender que la naturaleza de la responsabilidad ministerial era jurídica, hay otra destacable del mismo en lo que al carácter de la responsabilidad se refiere. Esta intervención tuvo lugar no ya en relación directa con los artículos relativos a la regulación de la responsabilidad, sino con el art. 71 del proyecto (art. 76 de la redacción definitiva del texto) referente a la periodicidad de reunión de las Cortes y la posibilidad de disolución por el Monarca. De nuevo se citaba como modelo Inglaterra, al señalar que allí la reunión del Parlamento estaba asegurada por la necesidad del Rey de convocarla para la aprobación de subsidios, pero, en el caso de la nación española, "no estando acá en igual necesidad, es menester algo que la supla, a lo menos una gran responsabilidad en los Ministros, o que pasados tres años sin convocación de Cortes, por el mismo hecho se tenga destituido de su empleo a aquel a quien corresponda expedirla y no se obedezca orden que por él se comuniquen.

Se trataba, por lo tanto, de garantizar la convocatoria de las Cortes e impedir la arbitrariedad del Monarca que, mediante la disolución o la correlativa ausencia de convocatoria, podría dar lugar a que las previsiones constitucionales o bien fueran incumplidas (no convocándose trienalmente), o bien adulteradas (procediendo a la inmediata disolución de Cortes una vez reunidas éstas). El mecanismo de garantía lo constituiría la exigencia de responsabilidad, aquí entendida, por lo tanto, como un instrumento del que dispondrían las Cortes para su autotutela. La construcción de PEREYRA es sumamente interesante, puesto que permite vislumbrar un acercamiento a una responsabilidad política, por lo que habrá de aquilatarse en toda su dimensión: en primer lugar, hay una superación de la responsabilidad por meros actos de ejecución. La convocatoria de las Cortes, o su disolución, constituyen actos netamente discrecionales ${ }^{37}$

vigente en el siglo XVIII, se seguirá afirmando por Dicey en 1885. Vid. A. V. DICEY, Introduction to the Study of the Law of the Constitution (1885), Macmillan Education LTD, 1985, pág. 327. En el mismo sentido se pronunciaría Anson; Cfr. William R. ANson, The Law..., op. cit., part. l: Parliament, pág. 302.

${ }^{37}$ Parte de la doctrina actual ha llegado incluso a mantener que los actos políticos del Gobierno infiscalizables por vía judicial, se circunscribirían tan sólo a estas relaciones políticas Gobierno-Parlamento. En un sentido más ecléctico, Laferrière incluye estos actos como típicamente políticos, si bien no de forma exclusiva. Cfr. LAFERRIĖRE, Traité de la jurisdiction administrative, Berger-Levrault et Cia., París, 1896, vol. II, pág. 35. 
y son éstos los que tratan de ser sujetos a responsabilidad. Aquí no se trataba de controlar la ejecución de una ley u orden, sino la propia discrecionalidad de la decisión de convocatoria o disolución de Cortes. Nos encontramos con un mecanismo que intentaba realmente limitar un ámbito de poder discrecional.

Es cierto, sin embargo, que este intento de limitación encontraba a su vez restricciones que venian dadas por la posición suprema que ostentaba el Monarca. La decisión de convocatoria y disolución correspondía a éste, pero no podía exigírsele responsabilidad por su carácter inviolable, por lo que, como ocurría con el resto de decisiones políticas, se hacía a los ministros sujetos imputables. Ahora bien, hay una cierta diferencia entre exigir responsabilidad a los ministros por llevar a cabo una actividad ejecutiva contra legem y la responsabilidad que se les exigiría por ejecutar una orden regia de disolución de la cámara. La semejanza sería, claramente, que en ambos casos mediaba la ejecución (la disolución de la cámara requería orden regia que sería ejecutada por los ministros); sin embargo, los parámetros utilizados por las Cortes para enjuiciar la ejecución ya no serían las normas (en concreto, no sería la orden regia), sino que, de suceder el caso, el parámetro sería de oportunidad. Esto se desprende de las palabras de PEREYRA: había que hacer responsable a algún sujeto $y$, no pudiendo ser el Rey, habrian de serlo necesariamente los ministros, pero lo que se estaba juzgando no era esa ejecución, sino que, en realidad, se estaba poniendo en tela de juicio la oportunidad política de la decisión (discrecional) de disolver las Cortes o de no convocarlas.

Por otra parte, la aportación del diputado al Estatuto suponía además un cambio importante en la regulación genérica de responsabilidad que establecía el articulado constitucional. Este cambio vendría dado porque ya no se trataba sólo de exigir responsabilidad ante la ejecución positiva de una orden (como sería el caso de la disolución de las Cortes), sino que también se brindaba la posibilidad de exigirla ante una omisión, esto es, en el caso de no producirse la convocatoria. En este último supuesto es evidente que no había acto jurídico alguno que ejecutar $y$, por lo tanto, la máxima de que los ministros eran sólo responsables de la ejecución de leyes y órdenes se vendría abajo. Es más, en este sentido, la regulación propuesta sería incluso más avanzada que la de la Constitución francesa del año VIII. Esta última reconocía, como se ha visto, la responsabilidad de los ministros por inejecución de leyes y reglamentos, pero en la opción de PEREYRA no se trataba ya de una inejecución, que presupone la existencia de un acto previo a ejecutar, sino de la exigencia de responsabilidad aun cuando no existiese acto alguno que ejecutar. Por esta razón, la propuesta del diputado iba más allá de la simple responsabilidad jurídica, al pretender fiscalizar la propia acción gubernativa dis- 
crecional lo sea, la decisión política de convocar, que corresponde al Rey), utilizando parámetros no normativos, sino políticos. Otra cosa distinta es que la exigencia de responsabilidad no alcanzase al auténtico órgano decisorio, el Monarca, pero resulta perfectamente lógico habida cuenta de la posición suprema del mismo. De esta manera, no quedaba más remedio que hacer responsables a los ministros por actos que se integraban en la función propiamente de gobierno, a pesar de no haber mediado actividad ejecutiva alguna por su parte.

Una última cuestión a tratar es la del órgano competente para exigir esa responsabilidad. En este aspecto, el diputado PEREYRA guardaba silencio. Era, en realidad, un punto problemático: si las Cortes no han sido convocadas o han sido disueltas no podrían ser éstas quienes ejerciesen esta acción. Quizás la solución deba inferirse de la expresión "se tenga por destituido", que daba a entender que PEREYRA apoyaba la redacción de una prescripción constitucional en la que se impusiera directamente la sanción de destitución sin necesidad de mediar la intervención de órgano alguno.

La parquedad de datos sobre las discusiones de la Junta, así como la ya predicada pobreza del debate constitucional, impiden llegar más allá en la disquisición y ponderar en qué medida tales propuestas fueron apoyadas o rechazadas por otros oradores. La ausencia de referencia en las Actas deja entrever la escasa repercusión que tuvieron estas aportaciones; aportaciones que, sin duda alguna, hubieran suscitado un rico debate en otro foro no tan imbuido por una genérica demisión.

\section{Instrumentos de exigencia de responsabilidad}

El diputado PEREYRA no se conformaba, sin embargo (lo cual es ciertamente loable, habida cuenta del abandonismo general de la Junta), con la regulación del Estatuto y arremetió igualmente contra el art. 85, en el que se fijaba la potestad de las Cortes para exigir responsabilidad a los ministros. Esta previsión normativa le parecía insuficiente: "Tampoco basta hacerlos responsables de esto (referido a la responsabilidad por las órdenes ministeriales expedidas contra legem) si no se declara por quién, ante quién, cuándo y en qué manera podrán ser reconvenidos".

La intervención de PEREYRA alude a otra cuestión: el instrumento a través del cual las Cortes exigían la responsabilidad. Concretamente, el art. 85 hablaba de "quejas", que debían expresarse en una "representación". Ésta se votaba y posteriormente se remitía al Monarca a través de una diputación. 
El concepto "quejas" resultaba impreciso, y así lo hizo ver PEREYRA: "No se dice alli (en el art. 85) si los particulares que se sientan agravados podrán acudir a las Cortes, ni de qué manera deberán hacerlo y justificar sus quejas; $y$ aun parece que sólo se trata de quejas generales de la Nación".

Esta duda que se planteaba el diputado viene en gran parte motivada, y es preciso insistir en ello, por la ausencia de medios de control para conocer y contrastar la actividad ejecutiva de los ministros, a no ser la comparecencia del ministro de Hacienda. Está claro que si las Cortes debían manifestar las quejas que tuviesen sobre la conducta ministerial, antes habrían de conocer ésta, y del articulado - según entendía PEREYRA - podía desprenderse que dicho conocimiento provendría de las protestas que manifestaran a la asamblea los propios ciudadanos. De esta forma, habría un mecanismo nuevo de información para proceder a enjuiciar la acción ministerial. La tesis de este diputado llevaria a convertir a la cámara en una especie de tribunal de apelación o de garantía de derechos, cuando no parecía ser ésta la intención del Estatuto, que no reconocia tal función a las Cortes ni establecía mecanismo alguno para hacerle llegar las quejas. Por otro lado, la función de garantía de derechos parece claro que se reservaba al Senado, si bien restringida a la tutela de dos únicos derechos: la libertad personal y la libertad de imprenta (únicos derechos, por otra parte, que reconoce expresamente el Estatuto, aparte de la inviolabilidad del domicilio y ciertas garantías procesales).

Lo que sí es cierto, aunque sea situarnos en el plano de la ficción juridica y de las hipótesis, es que un concepto tan genérico como el recogido en el art. 85 ("quejas») podría haber dado lugar, en un desarrollo normal del Estatuto en la vida jurídica, a una evolución hacia la exigencia de responsabilidad política. A pesar de reconocerse la exclusiva responsabilidad por actos de ejecución, no es descartable que, al reconocer a las Cortes la posibilidad de plantear "quejas", en abstracto (sin especificar si lo eran por actos de ejecución o por cualquier otro, a pesar de que una interpretación sistemática nos lleva a la primera opción) se permitía que las prácticas constitucionales acabaran por utilizarlo como un cajón de sastre en el que se incluyeran quejas de todo tipo.

El art. 85 establecía también que estas quejas se votarían e incluirian en una representación remitida al monarca, lo que deja patente que las Cortes se ubicaban tan sólo en un primer momento de la exigencia de responsabilidad (lo que podríamos Ilamar "acusación", o "exigencia de responsabilidad difusan), de manera que les correspondía únicamente controlar y solicitar la aplicación de la sanción en caso de resultar negativo dicho control. 


\section{La cuestión de la publicidad de las sesiones}

Antes de culminar esta parte de la exposición, resulta de interés apuntar una última cuestión. Como se acaba de decir, las Cortes exigian responsabilidad, pero no aplicaban la sanción, de manera que sus conclusiones no eran vinculantes. Sin embargo, la exigencia de responsabilidad, aparte de la sanción propiamente aneja de separación de cargo, tiene una vertiente que podríamos llamar de "presión pública». Conforme a ésta, las asambleas utilizan los instrumentos de control y exigencia de responsabilidad con el fin de dar publicidad e influir en la opinión públi$\mathrm{ca}^{38}$. Desde esta perspectiva, las Asambleas, al exigir la responsabilidad, actúan como "cámaras de resonancia" que dan publicidad a la actividad gubernamental y a la crítica a la que se somete; pero para cumplir esta misión se requiere, a fortiori, una característica de organización y funcionamiento del Parlamento: la publicidad de las sesiones ${ }^{39}$. Sin este requisito mal podrá conocerse la reprobación del ejecutivo. Es éste precisamente el asunto en que es necesario incidir ahora al analizar la responsabilidad en el Estatuto de Bayona. Evidentemente, el papel de la opinión pública en el sistema sujeto a examen debe ser tratado con grandes cautelas, toda vez que, al no ser el ejecutivo de elección popular (directa o indirectamente), a pesar de que pudiera formarse una voluntad popular contraria al mismo, ésta no habría podido "sancionarlo" mediante la no reelección ${ }^{40}$. Sin embargo, el papel de la opinión pública ha sido tenido en cuenta incluso por la doctrina tradicional ${ }^{41}$.

38 Vid. Giusseppe Ugo Rescigno, La responsabilità politica, Giuffrè, Milano, 1967, pág. 116, donde construye el concepto de responsabilidad política difusa en torno a la necesidad de libertad crítica por los sujetos de la comunidad política. En esta misma línea, Ivor Jennings afirma que la responsabilidad ministerial es el instrumento para asegurar que el gobierno actúa en armonía con la opinión pública. Vid. Ivor Jennings, The British Constitution, Cambridge at the University Press, 1971, pág. 151. En la doctrina española actual, esta misma postura puede hallarse en Francisco Rubio LLoRENTE, La forma del poder, Centro de Estudios Constitucionales, Madrid, 1993, págs. 209 y 254; y Manuel Aragón ReYes, Gobierno y Cortes, Instituto de Estudios Económicos, Madrid, 1994, pág. 23.

39 Al respecto, Carl Schmitt afirma que «lo esencial del Parlamento es la deliberación pública". Para Schmitt el parlamentarismo liberal ha elevado la discusión pública en la asamblea a dogma de fe: "La publicidad se transforma en el absolutamente eficaz instrumento de control". Vid. Carl ScHmirt, Sobre el Parlamentarismo, Tecnos, Madrid, 1990, págs. 43 y ss.

40 En los sistemas presidencialistas, en los que la rígida separación de poderes impide la remoción del Jefe de Estado por el Parlamento, la publicidad dada a la exigencia de responsabilidad y a los controles sobre el ejecutivo con el fin de influir sobre la opinión pública, cobra especial relieve, ya que puede determinar la caída de popularidad del líder y la consiguiente no reelección del mismo. Sobre este tema puede consultarse a Giuseppe Ugo Rescigno, La Responsabilità..., op. cit., 
La Constitución de Bayona preveía, muy al contrario de esta doctrina, el secreto de las sesiones parlamentarias. De esta manera, a las Cortes ni tan siquiera les quedaba el recurso de que, al exigir responsabilidad a los ministros, la publicidad influyera sobre la opinión pública para generar un foco de presión sobre el ejecutivo.

EI CONDE DE TORENO, en su catilinaria al "texto afrancesado", se percató de tal circunstancia y lo expuso con palabras que, por su claridad, merece la pena exponer integramente: "Desde luego nótase que falta en aquella Constitución lo que forma la base principal de los gobiernos representativos, a saber, la publicidad. Por ella se ilustra y conoce la opinión, y la opinión es la que dirige y guía a los que mandan en los estados así constituidos. Dos son los únicos y verdaderos medios de conseguir que la voz pública suba con rapidez a los representantes de una gran nación y que la de éstos descienda a todas las clases del pueblo. Son, pues, la libertad de imprenta y la publicidad en las discusiones del cuerpo o cuerpos que deliberan " "2. Añadía TORENO, apoyándose en una base doctrinal aportada en gran medida por sus contactos durante el exilio: «Por la última, como decía el mismo Burke, llega a noticia de los poderdantes el modo de pensar y obrar de sus diputados (...) conforme a la expresión del gran jurisconsulto Blackstone, se enteran los que gobiernan de las variaciones de la opinión y de las medidas que imperiosamente reclama" ${ }^{43}$.

Sin embargo, en el seno de la Junta tan sólo los diputados ARRIBAS y GÓMEZ HERMOSILLA tomaron la voz para exigir que las sesiones fueran públicas, aunque cupiese la posibilidad de declararse secretas por orden del Rey o solicitud de dos tercios de los diputados ${ }^{44}$.

pág. 122, en donde se admite que la no reelección como posible supuesto de responsabilidad política; Karl LoEWENSTEIN, Teoría..., op. cit., págs. 256 y ss; y Pierre PACTET, "L'évolutión contemporaine de la responsabilité gouvernementale dans les democraties pluralistes", en Mélanges offerts à Georges Burdeau. Le Pouvoir, LGDJ, París, 1977, págs. 203 y 205.

${ }_{41}$ Vid. Edmund Burke, "Pensamientos sobre las causas del actual descontento (1770)», en Textos Políticos, Fondo de Cultura Económica, México, 1984, pág. 271; Benjamin Constant, Principios de Política (1815), Aguilar, Madrid, 1970, pág. 88, y Jeremy Bentham, First Principles Preparatory to Constitutional Code (1822), Clarendon Press, Oxford, 1989, pág. 56.

42 CONDE DE TORENo, Historia del levantamiento..., op. cit., págs. 86 y ss.

43 Ibidem, pág. 87.

${ }^{44}$ Respecto al tema tratado, la intervención de estos diputados (observación de 26 de junio de 1808) es la única que figura en las Actas de la Junta. 


\section{El órgano sancionador: la Comisión}

Como se ha visto, las Cortes, al apreciar indicios de responsabilidad, manifestaban sus quejas por escrito en una representación previamente votada que era elevada al monarca. "Examinará esta representación - dice el art. 85 en su párrafo segundo-, de orden del Rey, una comisión compuesta de seis consejeros de Estado y de seis individuos del Consejo Real».

El Estatuto no contenía otras especificaciones, dejando inconclusa la virtualidad de la decisión que adoptara la Comisión así constituida. De esta carencia se percataron los diputados ARRIBAS, GÓMEZ HERMOSILLA y PEREYRA que, como parece evidente, centralizaron el escaso debate que suscitó el tema de la responsabilidad.

PEREYRA se remitía al respecto a lo observado sobre la eficacia que habría de dársele a las decisiones de la junta ante la que el Senado podía, a su vez, exigir responsabilidad a los ministros, y respecto de la cual tampoco había previsión normativa alguna: "No se expresa qué valor ha de tener la decisión que dé la Junta después del examen, ni cómo ni por quién haya de ejecutarse; lo que parece fuera menester para que no fuese ilusoria la disposición de este artículo".

ARRIBAS y GÓMEZ HERMOSILLA iban más lejos, al defender la solución que habría de darse a la deliberación de la Comisión: «Pudiera añadirse: y si esta Comisión la encuentra justa (la representación de Cortes), el Rey separa al Ministro".

La laguna del articulado no puede superarse sino mediante una interpretación lógica y sistemática. Es claro que los ministros eran nombrados y separados por el Rey, contando con su exclusiva confianza. A pesar de que las Cortes podían controlar su acción y, llegado el caso, requerir la sanción, no podían, lógicamente, proceder a la separación del ministro, ni éste tenía razón para dimitir de su cargo, puesto que no había vinculación alguna entre ambos órganos; el ministro no requería de la confianza de las Cortes ni para su nombramiento ni para su pervivencia en el cargo. De esta manera, al Rey le correspondería en última instancia aplicar la sanción del ministro y hacer efectiva la responsabilidad.

El papel de la Comisión que examinaba la representación remitida por las Cortes no podía ser decisorio o vinculante, sino consultivo, con lo que se venía a corroborar aquella característica del edificio napoleónico conforme a la cual el órgano dirigente (en este caso el Rey) se rodeaba de órganos consultivos, correspondiendo la decisión última a su persona. 
Ahora bien, parecía contradictorio que, en numerosos casos, pudiera el Monarca sancionar a los ministros por ejecutar órdenes contra legem dictadas por él mismo. Así lo vio el diputado PEREYRA, que no encontraba lógica alguna a tal posibilidad: «La responsabilidad que aquí se impone a los Ministros (art. 31), parece en algún modo contradictoria. Un Rey mal informado, puede dar órdenes contrarias a las leyes; y si las expide el Ministro podrá, según este artículo, ser acusado de violación de éstas, y si no las expide, de contravención a las mismas órdenes".

Por una parte, PEREYRA hacía suya la premisa de que el Rey no podía equivocarse, al menos intencionadamente, pero por otra parte confesaba su perplejidad por responsabilizar a los ministros de actos ilegales que ellos no habían dictado. Conforme a lo expuesto, los ministros se hallarían, ciertamente, en una encrucijada: o expedir la orden ilegal y ser entonces responsables (lo que llevaría en última instancia a que el Rey pudiera sancionarles por aquéllas órdenes que él mismo había dado), o negarse a la expedición, pudiendo ser acusados entonces de desobediencia.

Este problema era el fruto de dos circunstancias: de un lado, la de hacer sujeto responsable a quien no habia adoptado la decisión ilegítima $y$, de otro, la de la exclusiva confianza regia que sustentaba a los ministros responsables. Apenas siete años después del momento de redacción del texto de Bayona, uno de los más brillantes publicistas franceses del siglo XIX, BENJAMIN CONSTANT, se percatará de esta circunstancia y acabará por concluir que era preciso mantener en toda su amplitud la ficción de que el Rey no podía equivocarse, y ello a pesar de la posibilidad de que «un monarca puede ordenar a sus ministros actos culpables y perdonarlos después» ${ }^{45}$ y, a sensu contrario, podría castigarlos por esos mismos actos.

\section{SUJETOS ACTIVOS DE LA RESPONSABILIDAD: EL SENADO}

La originalidad del papel garantístico que desempeñaba el Senado se acentuaba al atribuírsele otra función que no hacía sino complementar las anteriores: la exigencia de responsabilidad de los ministros.

45 Benjamin Constant, Principios..., op. cit, pág. 86. Sobre el pensamiento de este autor resulta imprescindible la consulta de Paul BASTID, Benjamin Constant et sa doctrine, Armand Colin, París, 1966, 2 vol. Más recientemente, en la doctrina española el profesor Varela Suanzes ha analizado la doctrina de Constant en su artículo "La Monarquía en el pensamiento de Benjamin Constant (Inglaterra como modelo)", Revista del Centro de Estudios Constitucionales, núm. 10, 1991, págs. 121 y ss. 
El Senado ejercía su misión fiscalizadora exclusivamente en relación con aquellas funciones que desempeñaba, esto es, la garantía de libertades públicas, de manera que no sólo controlaba cuándo habia infracción de éstas, sino que, si la infracción procedía de un ministro, podía recabar responsabilidades. La otra función específica del Senado, la garantía constitucional, no encontraba, sin embargo, correspondencia con un mecanismo de responsabilidad: podía, como ya se ha tratado, anular por inconstitucionales los actos de las juntas de elección, pero no podía exigir responsabilidades por tal infracción. En este sentido, el sistema se encontraría plenamente integrado si fueran las Cortes quienes procedieran en esos casos a exigir la responsabilidad ${ }^{46}$, lo cual tendría pleno sentido, puesto que eran éstas quienes controlaban los actos de ejecución contrarios a las normas. En tal caso, el Senado controlaría la actividad administrativa, declarándola inconstitucional, y las Cortes exigirían responsabilidad por la misma, fundándose en que se había producido infracción de una norma jurídica (la Constitución). Sin embargo, recuérdese que los ministros eran responsables por la ejecución de órdenes y leyes, sin referencia alguna a la norma constitucional (referencia que la Constitución del Año VIII sí hace en su art. 72, lo que lleva a pensar que la omisión pudo ser expresa), por lo que en principio habría que excluir esta posibilidad.

En el caso del Senado es obligado repetir la división que se ha hecho al tratar de las Cortes entre órganos que exigen la responsabilidad (como el Senado) y órganos que aplican la sanción.

\section{El Senado como órgano controlador y sujeto activo de responsabilidad}

El Senado garantizaba la libertad personal y de imprenta mediante dos Juntas constituidas en su seno: la Junta Senatoria de Libertad Individual y la Junta Senatoria de Libertad de Imprenta. La posibilidad de controlar la acción de los ministros se lograba a través de dos mecanismos: el primero, y sólo válido para la libertad personal, consistía en un parte que, obligatoriamente, el ministro de Policía General debía remitirle de las prisiones que se hubieran efectuado bajo indicios de conspiración contra el Estado (arts. 40 y 134). Se trataba, por lo tanto, de un ins-

46 Recuérdese que esta posibilidad se preveía en la Constitución de Frimario, cuyo art. 72 decía que "Les ministres sont responsables: 1. De tout acte de Gouvernement signé par eux, et déclaré inconstitutionnel par le Senat». 
trumento de inspección. El otro instrumento era la denuncia directa, ejercida mediante petición, de los particulares que hubieran sufrido la lesión de sus derechos, con ciertas limitaciones de capacidad procesal: respecto a la libertad individual, podían recurrir los detenidos personalmente o a través de parientes o representantes, en tanto que, respecto a la libertad de imprenta, podían recurrir los autores, impresores y libreros afectados. Debía haber, por tanto, un interés directo en el asunto. A través de este instrumento el Senado aparecía como un auténtico tribunal, ejerciendo funciones propiamente judiciales.

Mediante ambos mecanismos se dotaba al Senado de medios para conocer la actividad ejecutiva de los ministros (primera fase del control, o sea, la inspección) y proceder a su valoración (segunda fase del control, juicio). Para ésta última se expresaban incluso los parámetros que debía utilizar el Senado para poder calificar la conducta denunciada: el interés del Estado (arts. 42 y 47 ).

La regulación era, como puede comprobarse, mucho más detallada que la relativa a las Cortes ${ }^{47}$; se expresaban nítidamente mecanismos de control, sujetos que podían poner en marcha el procedimiento e incluso los parámetros valorativos que habían de utilizarse.

Respecto a éstos es destacable el propio término «interés del Estado", puesto que se trata de un concepto jurídico indeterminado que dejaba al Senado un enorme margen de valoración. Era él quien había de interpretarlo, arrogándose así una laxitud en la ponderación de la que carecían, muy a la contra, las Cortes. De esta manera, no teniendo que ceñirse a cánones normativos, siempre menos flexibles, era en el Senado donde auténticamente se abría la posibilidad de un control político sobre los ministros, si bien éste se encontraría circunscrito a las infracciones de libertades cuya garantía, en cuanto le correspondía al mismo, legitimaba este control.

47 Una valoración política podría llevar a considerar que la diferencia de trato de uno y otro órgano se justificaria por su distinta composición. En efecto, el Senado era esencialmente de nombramiento regio, hasta el punto de que ha sido concebido como un órgano de la Corona (cfr. Antonio Torres del Moral, Constitucionalismo..., op. cit., pág. 30), mientras que las Cortes eran un órgano de elección popular. La participación en el proceso político que Napoleón reservaba para éstas últimas era muy limitado y una buena manera de lograrlo pudiera ser mediante una regulación criptica, de forma que no se le restaban expresamente facultades pero tampoco se le reconocian. Si a esto añadimos que toda facultad que no correspondía a otro órgano debería entenderse integrado en las prerrogativas regias, la ratio legis cobra inmediatamente sentido. 
De resultar que los actos que hubieran ocasionado la detención del sujeto reclamante de tutela ante el Senado, o que la impresión de libros suspendida no fueran contrarios al "interés del Estado", las Juntas estaban legitimadas para solicitar al ejecutivo la revocación de las actuaciones. El requerimiento se efectuaría directamente al ministro que habia dado la orden de prisión (en el caso de la libertad personal) o la orden atentatoria contra la libertad de imprenta (arts. 42 y 47). Sin embargo, es menester hacer una puntualización: la intimación de la Junta Senatoria de la Libertad de Imprenta podía afectar a cualquier ministro infractor, con abstracción de su cartera, en tanto que la solicitud de la Junta Senatoria de Libertad Individual sólo podía referirse al Ministro de Policía. ¿A qué se debe semejante distinción? En tanto que cualquier ministro podía expedir mandatos lesivos de la libertad de imprenta, el atentado a la libertad personal, sin embargo, derivaba necesariamente de una orden del Ministro de Policía, único competente para decretar la prisión de los sospechosos de conspiración contra el Estado, conforme al art. 134. Con ello, se concluye que tan sólo dicho ministro podía ser sujeto pasivo de la responsabilidad por vulneración de la libertad personal. Si después de haber hecho tres requisiciones con este fin la actividad ilegítima se mantenía, la Junta Senatoria lo proponía a votación del pleno del Senado que, en su caso, pronunciaría una declaración manifestando la lesión de los derechos tutelados (arts. 43 y 48 ).

Comenzaba, asi, el momento de exigencia de responsabilidad que, como se ha dicho, no correspondía al Senado sancionar (lo que implica que sólo de forma "difusa» exigía esa responsabilidad), sino a un órgano que se analizará a continuación.

\section{El órgano sancionador: la Junta}

La deliberación del pleno del Senado sería examinada, de orden del Rey, por una junta compuesta por "los presidentes de sección del Consejo de Estado y de cinco individuos del Consejo Real" (art. 44), composición, como vemos, muy semejante a la Comisión que examinaba las quejas de las Cortes. Al igual que con éstas, había de nuevo una omisión sobre las consecuencias de la deliberación de esta junta. Como se ha dicho al tratar de la Comisión, tan sólo los diputados ARRIBAS, GÓMEZ HERMOSILLA y PEREYRA intervinieron en la Junta de Bayona para solicitar que se llenaran estas lagunas, que depauperaban la regulación de la responsabilidad. Se aprecia, no obstante, una diferencia en las intervenciones. PEREYRA, según se ha visto, trataba a esta junta de forma idéntica a la Comisión que debía conocer de las quejas de las Cortes. No suce- 
día así con ARRIBAS y GÓMEZ HERMOSILLA, que, si bien defendieron el carácter vinculante de las resoluciones de ésta última, respecto a la junta se limitaron simplemente a decir que usería de desear que se explicasen por menor las obligaciones y facultades de esta Junta, y se dijese qué uso hará el Rey de su resolución".

Lo auténticamente relevante era, por ende, garantizar que los ministros no pudieran mantenerse en el cargo si la Comisión consideraba justificadas las quejas de las Cortes. La garantía de que las resoluciones adoptadas por el pleno del Senado encontraran efectividad si la junta deliberadora las consideraba adecuadas, no parecía gozar para estos diputados de igual favor y necesidad de concreción o, al menos, no tenía por qué implicar necesariamente la separación de cargo del ministro inculpado.

\section{LA ALTA CORTE NACIONAL: PROBLEMÁTICA DE SU ARTICULACIÓN CONSTITUCIONAL}

La Junta de Bayona llegó a votar la proposición de que las decisiones de la junta y de la Comisión fueran vinculantes ${ }^{48}$. La incertidumbre y falta de preparación de los diputados se ejemplifica palmariamente en esta votación, puesto que, una vez aprobada por el pleno esta propuesta, se suspendió la misma cuando "hizo presente uno de los individuos que, hallándose como se hallaba pendiente (...) otra observación relativa a si se establecería o no una Alta Corte Nacional, la resolución que sobre ella recayese dejaría determinado el punto que acaba de ventilarse, y sin efecto su decisión, caso de que se opinase por la creación de aquel Supremo Tribunal, porque sin duda sería una de sus atribuciones el conocer de las deliberaciones del Senado en los casos especificados, y sobre la conducta de los Ministros cuando hubiese motivos legítimos para ello, y se reconoció que lo que se dejaba resuelto debía quedar en suspenso".

El aspecto más destacable de la cita lo constituye, sin duda, la confusión de facultades entre los órganos estatales, concretamente entre Cortes, Senado y poder judicial. La existencia de una junta y de una Comisión que decidieran las cuestiones planteadas por Senado y Cortes, respectivamente, chocaba con la pretensión de la Junta de Bayona de crear un órgano judicial, al que llamaban "Alta Corte Nacional»: «Propúsose en este lugar la creación de la Alta Corte Nacional en virtud de las

48 Acta Décima, de 28 de junio de 1808. 
observaciones que se habian hecho, de lo conveniente que era tener constitucionalmente establecido un tribunal determinado para conocer de las causas que pudiera ser necesario formar a personas de alta jerarquía ${ }^{49}$. Este supremo tribunal ocuparía la posición que el proyecto constitucional preveía para la junta y la Comisión sancionadoras. De esta manera, Cortes y Senado controlarían y exigirían responsabilidad por la actividad ministerial $y$, subsiguientemente, un órgano puramente judicial haría efectiva dicha responsabilidad. Esta circunstancia se justifica por el hecho de que la responsabilidad exigida por Cortes y Senado no dejaba de ser fruto de una infracción de normas (y por tanto de responsabilidad jurídica): violación de leyes u órdenes regias en un caso y lesión de derechos individuales en el segundo, por lo cual correspondería su conocimiento a los órganos judiciales. La única solución para mantener la existencia de la junta y Comisión conjuntamente con la de la Alta Corte sería, en tal caso, detraer del conocimiento del Supremo Tribunal aquellas causas que hubieran sido previamente conocidas por dichos órganos estatales o efectuar una separación de materias ${ }^{50}$. Sin embargo, esta opción no era factible, puesto que si bien se podían sustraer de su conocimiento las causas relativas a libertades individuales (objeto, por tanto, del Senado), no podia decirse lo mismo de las materias que conocía las Cortes. Materias que, en principio, gozaban de una "vis atractiva" que les permitía ponderar toda infracción de leyes y órdenes regias, cualquiera que fuera la materia que tratase. Es por esta razón que en el debate se entendió que, necesariamente, la inclusión de este tribunal supremo tendría que alterar las funciones (e incluso puede que la misma existencia) de la junta y de la Comisión.

La Alta Corte Nacional acabó por incorporarse al articulado (con el nombre de "Alta Corte Real»), concretamente en los arts. 108-111 (incardinados en el Título XI, rubricado "Del Orden Judicial», lo que deja claro su carácter judicial). Conocería de los delitos personales cometidos por miembros de la familia real, ministros, senadores y consejeros de Estado y sus sentencias sólo serían ejecutivas si eran firmadas por el Rey. Así pues, si era competente para conocer los delitos de los ministros en nada se diferenciaban sus competencias de las de la junta o la Comisión, que ejercian las mismas funciones, por lo cual la inclusión de este órga-

49 Acta de la Junta Décima, de 28 de Junio de 1808. La Alta Corte Nacional se compondría de ocho senadores, los seis presidentes del Consejo de Estado y presidente y vicepresidentes del Consejo Real.

${ }_{50}$ Conforme a esta solución, cuando acusaran las Cortes conocería la Comisión, cuando lo hiciera el Senado conocería la Junta, y en los demás casos de infracciones de los ministros conocería, como "alta jerarquía» que eran, la Alta Corte Nacional. 
no por parte de los diputados (una de las pocas que, por otra parte, aceptó Napoleón), sin haber procedido previamente a suprimir aquellos otros órganos o delimitar la separación de funciones entre los mismos y el supremo tribunal, hubiera sido fuente de conflictos ${ }^{51}$.

Sin embargo, la Alta Corte no alteraba, en puridad, el carácter consultivo que también se asignaba a la junta y a la Comisión: la diferencia era que respecto a éstos no se decía qué virtualidad tenía su decisión (aunque hemos visto que no sería decisoria), mientras que respecto a la Alta Corte se especificaba con precisión que su resolución revestiria una forma jurídica determinada (sentencia), pero la intervención regia también era necesaria, en la medida que la sentencia no surtía efectos sin su firma (jurisdicción retenida). Por consiguiente, la decisión última, ya se sustanciase la responsabilidad ante la junta, Comisión o ante la Alta Corte, correspondía siempre al Rey.

\section{CONCLUSIONES}

El Estatuto de Bayona presenta unas características muy peculiares dentro de la historia constitucional española del siglo XIX, en gran parte motivadas por haberlo concebido Napoleón como instrumento para someter a la nación española.

La Constitución dividía las facultades entre diversos órganos, si bien el núcleo del sistema era el Monarca. No puede olvidarse que, al garantizar la posición dominante del Monarca, Napoleón consolidaba también su propia hegemonía sobre el territorio conquistado. Nada le podía interesar más que concentrar los poderes en manos de miembros de su

51 La única vía de escape era el art. 111, que reservaba a la ley la regulación de las "facultades y modo de proceder de la Alta Corte Real». La Constitución Francesa del Año VIII guardaba cierta semejanza con la regulación de Bayona. El "Tribunat" denunciaría las infracciones de los ministros, el Cuerpo Legislativo deliberaría sobre las mismas y finalmente juzgaría "une Haute-Cour». Como en el Estatuto, esta regulación era posible porque la responsabilidad que exigian "Tribunat" y "Corps Législatif» era jurídica, y por lo tanto había de resolver un tribunal. La única diferencia con un proceso ordinario era de carácter subjetivo, esto es, el carácter del reo. Debido a que se trata de una alta jerarquía sólo podían acusar "Tribunat" y "Corps Législatif" y enjuiciar la "Haute-Cour». Sin embargo, la Constitución francesa no incorporaraba órganos intermedios, como hace el Estatuto con la Comisión y la Junta; órganos que, al ser competentes para conocer de las infracciones de los ministros, generaban un conflicto de competencias. 
familia y sustraer toda intervención decisiva de órganos nacionales, para influir e incluso imponer su política.

El Monarca se rodeaba de órganos esencialmente consultivos y era el centro de adopción de decisiones que materializaba a través de un vasto poder normativo en el que el resto de órganos estatales, incluidas las Cortes, participaban de forma exigua. Estas decisiones políticas eran ejecutadas por sus ministros, agentes regios que no se integraban en un gabinete, sino que se mantenían independientes entre sí.

La ejecución ministerial era susceptible de control por dos órganos: Cortes y Senado. Ambos podían, de juzgar negativa la conducta ministerial, exigir responsabilidad y acusar a los ministros ante otros órganos: la Comisión en lo que a las quejas de Cortes se refiere; la junta, por lo que respecta a las reclamaciones del Senado.

La tarea fiscalizadora de las Cortes se dividía en tres momentos:

A) Un primer momento, que puede llamarse de "inspección", en el que los poderes de las Cortes estaban muy mermados, pues no contaban con mecanismos especificos para indagar la actividad ministerial, a no ser la comparecencia del ministro de Hacienda ante la cámara para informar sobre el estado de las cuentas públicas. Comparecencia que, por otra parte, era lógica, habida cuenta de que eran las Cortes quienes aprobaban los presupuestos.

B) Un segundo momento, de "juicio". La asamblea debía, una vez conocida la acción ministerial, comprobar si ésta era conforme a las leyes y órdenes regias, lo que exigía un control jurídico, no político, y que su margen de apreciación, por lo tanto, fuera limitado, al tener que circunscribirse para valorar la conducta ministerial a las leyes y órdenes ejecutadas por los ministros.

C) Un tercer momento, de "exigencia de responsabilidad difusa" o de "acusación". Si la conducta ejecutiva resultaba contraria a las leyes y órdenes, las Cortes no podían sancionar directamente al ministro, puesto que éste no necesitaba contar más que con la confianza regia. La única facultad que les concedia el Estatuto era la de manifestar sus "quejas» a otro órgano. En otro orden, la asamblea ni tan siquiera podría utilizar este mecanismo de plantear quejas como un medio de presión indirecta sobre el ejecutivo ya que, al ser secretas las sesiones de Cortes, no se daba eco público a tales quejas, imposibilitando así la formación de una opinión popular contraria a los ministros. El órgano ante quien planteaba las Cortes sus quejas, llamado "Comisión" e integrado por miembros del Consejo Real y Consejo de Estado, examinaba la solicitud pero no deci- 
día tampoco, siendo el Monarca quien ejercía tal facultad, separando o no al ministro según su libre albedrío.

Por lo que al Senado se refiere, ejercía éste su fiscalización en conformidad con sus funciones de garantía de libertad personal y de imprenta. Las fases son idénticas a las establecidas para las Cortes:

A) Una fase de "inspección», en la que, frente a lo que ocurría con las Cortes, el Senado contaba con medios especificos. Los mecanismos consistían en la denuncia de particulares afectados (lo que supone concebir al Senado como órgano de apelación) y un parte que el ministro de Policía debía remitirles con las detenciones efectuadas. Ambos medios eran examinados por dos Juntas Senatorias.

B) Segunda fase, de «juicio». El Estatuto preveía que, para enjuiciar la actividad ministerial y, por lo tanto, juzgar si había habido detención ilegal o lesión de la libertad de imprenta, el Senado (más concretamente, las Juntas) utilizarían como criterio de ponderación «el interés del Estado", concepto éste muy vago que, sin duda, posibilitaría un control no sólo jurídico, sino también político de la acción ministerial. Así, frente a lo que sería habitual en las Constituciones decimonónicas, el papel de control político estaba en la de Bayona más justificado para el Senado que para las Cortes. Si de este juicio entendían las Juntas Senatorias que se derivaba una actividad lesiva de derechos por parte de los ministros, adoptaban una medida (no sanción) tendente a poner fin a la situación: podían requerirlos hasta tres veces para que ajustasen su conducta a la legalidad.

C) Tercera fase, de "exigencia de responsabilidad difusa" o de "acusación". Al igual que las Cortes, el Senado no era competente para sancionar la actuación ministerial. Así pues, de no ser atendidas las tres requisiciones de la Junta, ésta se limitaba a exponerlo ante el Pleno, que podía hacer una declaración de haber comportamiento ilícito del ejecutivo. Esta declaración era examinada por una junta integrada, como la Comisión, por miembros del Consejo Real y del Consejo de Estado, quien tampoco sancionaba al ministro responsable, sino que desempeñaba un papel deliberante, decidiendo el Rey.

Por lo que respecta a las deliberaciones en la Junta sobre el tema de la responsabilidad, aquéllas fueron muy escasas $y$, aunque en algún caso se aportó alguna idea de interés, lo cierto es que pronto se ahogaría en la tónica mediocre de la Junta de Bayona, hasta el punto de no suscitar discusión alguna. Los principales puntos sobre los que incidieron estas intervenciones fueron los de la necesidad de perfilar qué papel se daría a la junta y Comisión que conocían de las quejas y reclamaciones 
de Senado y Cortes, y respecto a las cuales había una absoluta oscuridad. Se defendió, y así lo aprobó la Junta de Bayona, que la decisión que tomaran fuera vinculante, si bien el texto final no lo recogeria, con lo que se mantenían íntegras las potestades regias. Otro punto sobre el que se suscitó un cierto debate fue el de la creación de un órgano judicial, la Alta Corte Nacional, que conocería de las infracciones de los altos cargos, incluidos los ministros. Esta previsión, que si llegaría a la redacción última de la Constitución, planteaba no pocos problemas que fueron en gran medida obviados por los diputados.

Era evidente, y así se hizo ver en la Junta de Bayona, que si la Alta Corte conocía en estos supuestos, la discusión sobre el papel que debiera darse a las resoluciones de la Comisión y la junta quedaba alterada, puesto que habría una identidad de objetos: ambos órganos enjuiciarían la conducta ministerial. Sin embargo, haciendo gala de poca congruencia, se aprobó, como se ha visto, la adhesión al proyecto de la Alta Corte, sin proceder previamente a retocar a los otros dos órganos (Comisión y junta), lo que, sin duda, de haberse aplicado el Estatuto, hubiera ocasionado más de un conflicto.

Lo que sí es cierto es que, aun cuando conociera de las infracciones de los ministros este órgano judicial, no por ello el Monarca perdía poder, puesto que las sentencias que recayesen no eran ejecutivas sin la firma regia.

En definitiva, la responsabilidad del Gobierno en el Estatuto de Bayona se concretaba en un sistema confuso y enmarañado que no desentonaba con la línea general de un texto que Napoleón tenía prisa en imponer y que los españoles que participaron en su definitiva elaboración no supieron o no pudieron corregir. 